\title{
RECENZJA
}

„Studia Wyborcze”, tom 27, 2019

DOI: https://doi.org/10.26485/SW/2019/27/7

\section{JURIJ BOHDANOWYCZ KLUCZKOWSKYJ, PRYNCYPY WYBORCZOHO PRAWA: DOKTRYNALNE ROZUMINNIA, STAN TA PERSPEKTYWY ZAKONODAWCZOJI REALIZACIJI W UKRAJINI, KYJIW 2018, SS. 908}

Zasady prawa wyborczego - jedno z centralnych zagadnień prawa konstytucyjnego (a także nauk o polityce) - są przedmiotem bardzo wielu opracowań. Recenzowana monografia zajmuje się nimi z punktu widzenia doktryny i praktyki ustrojowej Ukrainy z bardzo szerokim tłem prawnoporównawczym. To bardzo obszerne dzieło obejmujące blisko tysiąc stron druku. Nie sposób więc w krótkiej formie, chociażby pobieżnie, zrelacjonować wszystkich poruszanych w nim wątków. Zajmę się tylko niektórymi z nich, tymi które z punktu widzenia polskiego czytelnika, moim zdaniem, mogą być najbardziej interesujące ${ }^{1}$.

Książka składa się z dziesięciu rozdziałów, podzielonych na podrozdziały, oraz osobno wyodrębnione - wstęp i wnioski.

Rozdział pierwszy to autorskie spojrzenie na generalia związane z zasadami prawa wyborczego (miejsce prawa wyborczego w systemie prawa, istotę i rolę zasad prawa, w tym także prawa wyborczego, dla całego systemu prawa itp.), próba systematyki zasad prawa wyborczego, opis międzynarodowych standardów w tym zakresie, wskazanie znaczenia dla demokratycznych wyborów zasad praworządności i legalizmu, charakterystyka zasady przedstawicielstwa i cech mandatu przedstawicielskiego.

Sposób widzenia zasad prawa wyborczego przez Jurija Kluczkowskiego nawiązuje do ujęcia zasad prawa zaproponowanego przez Ronalda Dworkina i Roberta Alexy'ego. Zasady prawne ujmowane są przez nich jako rodzaj norm postępowania, w których wyróżnia się podklasę zasad i podklasę reguł. Zasadą jest taka norma, która stanowi argument za konkluzją, żeby powstała pewna konsekwencja prawna, ale nie wyznacza tych konsekwencji, które ,automatycznie" powinny nastąpić, jeżeli zachodzą przewidziane przez tę zasadę

1 Warto zauważyć, iż autor stosunkowo często odwołuje się do ustaleń polskiej doktryny. Na 230 obcojęzycznych źródeł przywoływanych w monografii 56 to źródła w języku polskim (ogółem bibliografia obejmuje imponującą liczbę 1467 cytowanych pozycji). 
okoliczności. Zasady prawa to normy, których spełnienie jest stopniowalne. Od reguł odróżnia je wymiar ,wagi lub doniosłości”, który pozwala rozstrzygać konflikty pomiędzy nimi. Reguły tego wymiaru nie posiadają, wszystkie są jednakowo ważne (doniosłe), jeżeli są sprzeczne, to jedna z nich jest nieważna. Poszczególne dyscypliny dogmatycznoprawne formułują własne ogólne założenia dla zasad prawa uznawanych za obowiązujące w danej gałęzi. Takimi zasadami są zasady prawa wyborczego przedstawiane przez J. Kluczkowskiego.

Dla dalszych rozważań szczególne znaczenie ma zaproponowany w tym rozdziale podział na cztery grupy zasad mających wpływ na szczegółowe regulacje prawne dotyczące wyborów (s. 83-84):

- I grupa - zasady właściwe dla całego systemu prawa (zasada praworządności, w szczególności zasada przestrzegania praw i wolności człowieka i obywatela oraz zasada legalizmu i pewności prawa).

- II grupa - konstytucyjne zasady demokracji przedstawicielskiej (suwerenności narodu, podziału władzy, pluralizmu politycznego, bezpośrednich, cyklicznych wyborów).

- III grupa - zasady właściwe dla prawa wyborczego (wyborów powszechnych, równych, wolnych, uczciwych i alternatywnych).

- IV grupa - zasady właściwe dla poszczególnych instytucji prawa wyborczego, w szczególności zasady dotyczące głosowania (tajności, osobistego jednokrotnego dobrowolnego głosowania).

Rozdział drugi to analiza zasady powszechności wyborów w trzech płaszczyznach: prawa głosowania, prawa kandydowania i prawa nominowania (zgłaszania kandydatów). Ostatni z wymienionych aspektów powszechności wyborów rzadko bywa przedmiotem refleksji naukowej, dlatego warto zwrócić szczególną uwagę na ten fragment rozważań J. Kluczkowskiego. Jego zdaniem za wyodrębnieniem samodzielnego prawa nominowania (a nie traktowaniem go jako elementu czynnego prawa wyborczego) przemawia między innymi to, że jest ono wyraźnie wskazane w przepisach prawa wyborczego (także ukraińskiego - s. 169). Analiza prawnoporównawcza doprowadza autora do wniosku, iż istnieją dwa punkty widzenia na to kto powinien być podmiotem prawa nominowania. Według pierwszego - wyborca, według drugiego - partie polityczne (s. 291-292).

Wśród opisów rożnego rodzaju cenzusów wyborczych, uwagę polskiego czytelnika zwrócić może charakterystyka cenzusu wykształcenia (s. 259-262), który na Ukrainie występuje w postaci wymogu ,władania językiem państwowym" (w odniesieniu do kandydata w wyborach prezydenckich - art. 103 konstytucji Ukrainy). Jest to realny problem w wielu państwach postradzieckich.

Trzeci rozdział monografii autor poświecił zasadzie równości prawa wyborczego (także w wymiarze prawa głosowania, prawa kandydowania i prawa nominowania kandydatów). W tej części szczególnie interesujące są, prowadzone 
w kilku płaszczyznach, rozważania dotyczące równości biernego prawa wyborczego. Chodzi o równość możliwości skorzystania z biernego prawa wyborczego (,stania się" kandydatem), równość statusu prawnego zarejestrowanych kandydatów oraz równość proceduralną kandydatów (równość udziału w procedurze wyborczej). W kontekście biernego prawa wyborczego poruszony został również problem równości płci (s. 365-369). Dużo miejsca zajmują także dociekania na temat równości partii politycznych w procesie wyborczym (s. 372-382).

Według autora zasada wolnych wyborów (rozdział czwarty) po raz pierwszy została wyrażona na konferencji przywódców koalicji antyhitlerowskiej w Jałcie, w odniesieniu do mających odbyć się po wojnie wyborów w Polsce (s. 385). Zasadniczym problemem, wokół którego koncentruje się treść tego rozdziału jest wpływanie na kształtowanie woli wyborców poprzez prowadzenie agitacji przedwyborczej. Autor zajmuje się między innymi wyodrębnieniem grup podmiotów, które taki wpływ mogą mieć, oraz tych, którym wpływania na kształtowanie woli wyborców prawo zabrania (np. cudzoziemców). Szeroko omawia problemy związane z kampanią wyborczą, w szczególności zagadnienie „ciszy wyborczej”, często przytaczając poglądy polskich uczonych (między innymi Jerzego Buczkowskiego, Ferdynanda Rymarza i Anny Rakowskiej-Treli - s. 418).

Zasada uczciwych (sprawiedliwych) wyborów według autora recenzowanej monografii została sformułowana końcem XX wieku w związku z procesem demokratyzacji w państwach o reżimach autorytarnych i totalitarnych. Ma ona mniejsze znaczenie dla „starych demokracji” ze społeczeństwami o wysokiej kulturze politycznej (s. 421).

W szerokim rozumieniu „uczciwość” wyborów wyklucza ich „pozorność”. Oznacza zakaz dyskryminacji jakichkolwiek partii politycznych, swobodną rejestrację kandydatów, niezależność i bezstronność administracji wyborczej, neutralne traktowanie kandydatów przez policję, armię i sądy, równe traktowanie kandydatów wysuwanych przez partie polityczne i kandydatów niezależnych, bezstronne edukowanie wyborców, co do ich praw, właściwe prowadzenie kampanii wyborczej z zachowaniem określonych zasad postępowania, równy dostęp do publicznych środków masowego przekazu, bezstronne udostępnianie funduszy publicznych partiom politycznym (gdy jest to dopuszczalne), nienadużywanie władzy dla celów prowadzenia kampanii wyborczej. W dzień głosowania „uczciwość” wyborów oznacza swobodny dostęp do miejsc, gdzie odbywa się głosowanie dla przedstawicieli partii politycznych, akredytowanych krajowych i międzynarodowych obserwatorów i środków masowego przekazu, tajność głosowania, zakaz zastraszania wyborców, efektywną formę kart do głosowania, odpowiednie urny wyborcze, bezstronną pomoc wyborcom (jeżeli to konieczne), odpowiednie procedury liczenia głosów, zabezpieczania kart do głosowania i transportu materiałów wyborczych, niezależną ochronę pomieszczeń w których odbywa się głosowanie. Po zakończeniu głosowania 
standard ,uczciwości” wyborów wymaga szybkiego oficjalnego ogłoszenia wyników wyborów, bezstronnego rozpatrzenia protestów wyborczych, bezstronnego ogłoszenia wyników wyborów w środkach masowego przekazu, uznawania wyników wyborów przez wszystkich zainteresowanych (s. 423).

W wąskim znaczeniu zasada uczciwych wyborów oznacza, że oficjalne wyniki wyborów powinny odpowiadać realnie wyrażonej woli wyborców (w uproszczeniu, wyniki wyborów nie mogą być fałszowane - s. 424-425).

Wymienione wyżej warunki uczciwych wyborów zarówno w wąskim, jak i szerokim znaczeniu są szczegółowo analizowane w poszczególnych podrozdziałach piątego rozdziału monografii J. Kluczkowskiego.

Kolejny rozdział to analiza zasad: wyborów bezpośrednich, wyborów cyklicznych (regularnych) i wyborów alternatywnych. Pisząc o zasadzie bezpośredniości autor bardzo szeroko przedstawia stanowisko polskiej doktryny prawa konstytucyjnego (tak szczegółowa relacja różnych poglądów rzadko zdarza się nawet w naszej, rodzimej literaturze przedmiotu ${ }^{2}$ ), przy czym stwierdza, iż traktowanie głosowania poprzez wskazanie konkretnego kandydata na liście komitetu wyborczego (nazywa to głosowaniem imiennym) jako elementu zasady bezpośredniości wyborów jest charakterystyczne dla Polski i nie powinno być przenoszone na grunt prawa ukraińskiego (s. 509).

Zasada cyklicznych wyborów według J. Kluczkowskiego oznacza, ,że dla każdego wybieranego organu (kolegialnego czy jednoosobowego) ma być ustanowiony sprecyzowany, wskazany z wyprzedzeniem okres pełnomocnictw, na jaki wybierany jest jego skład". To nie tylko zasada prawa wyborczego, ale także podstawa demokracji przedstawicielskiej (s. 511-512). Autor opisuje między innymi w jaki sposób, pod wpływem praktyki ustrojowej, doszło do wyznaczenia w konstytucji Ukrainy sztywnych terminów wyborów - parlamentarnych (w ostatnią niedzielę października w piątym roku kadencji Rady Najwyższej Ukrainy - art. 77), prezydenckich (w ostatnią niedzielę marca w piątym roku kadencji prezydenta Ukrainy - art. 103) oraz wyborów do rad wiejskich, osiedlowych, miejskich, rejonowych, obwodowych i wyborów przewodniczących rad wiejskich, osiedlowych, miejskich (także w ostatnią niedzielę października, w piątym roku kadencji właściwej rady lub właściwego przewodniczącego - art. 141).

Zasada wyborów alternatywnych wymaga, żeby „wyborca w czasie głosowania miał możliwość realnego wyboru z kilku wariantów (opcji), które poddawane są głosowaniu (kandydatów, list kandydatów)" - s. 519.

Badania porównawcze doprowadziły autora do wyodrębnienia trzech różnych sposobów regulacji postępowania w sytuacji, gdy mimo istnienia

2 Wystarczy chociażby przytoczyć nazwiska cytowanych autorów: M. Chmaj, K. Czaplicki, J. Galster, M. Granat, Z. Jarosz, S. Jaworski, K. Skotnicki, W. Skrzydło, A. Sokala. 
pluralizmu politycznego, w przewidziany prawem sposób zgłoszony zostaje tylko jeden kandydat lub jedna lista kandydatów (s. 519-522). Pierwszy polega na przeprowadzeniu wyborów z udziałem jednego kandydata i możliwością głosowania za lub przeciw takiej kandydaturze, drugi na odroczeniu terminu wyborów w określonym okręgu, celem stworzenia możliwości zgłoszenia większej liczby kandydatów, trzeci na ogłoszeniu wybranym jedynego zgłoszonego kandydata (listy kandydatów) bez przeprowadzania wyborów.

W rozdziale siódmym J. Kluczkowski przechodzi do zasad dotyczących głosowania. Zajmuje się zasadami głosowania: tajnego, osobistego, jednorazowego i dobrowolnego.

Pisząc o zasadzie tajności głosowania rozróżnia „słabą” i „silną” formę tej zasady. Pierwszą utożsamia z prawem wyborcy do zachowania tajemnicy głosowania, silną z obowiązkiem jej zachowania (s. 530-532). W kontekście zasady tajności porusza także kwestię zbierania podpisów na listach poparcia kandydatów (s. 536-538). Omawiając zasadę głosowania osobistego zajmuje się, między innymi, głosowaniem korespondencyjnym i głosowaniem przez pełnomocnika (s. 541-544), a zasadę jednokrotnego głosowania, sporządzaniem rejestrów i spisów wyborców (s. 544-547).

Zasada głosowania dobrowolnego (fakultatywnego) jest przeciwieństwem obowiązku głosowania i w taki sposób jest w monografii analizowana (s. 548-557).

Kolejny (ósmy) rozdział ma nieco inną konstrukcję. Poświęcony jest „,procesowi wyborczemu" i jego zasadom. Autor uznał za stosowne szerokie omówienie elementów składających się na regulację procesu wyborczego, a jego zasadom poświecił tylko jeden z podrozdziałów. Według niego naukowcy z innych krajów, w tym polscy, mało uwagi poświęcają proceduralnym aspektom wyborów (s. 558). Proces wyborczy definiuje jako normatywnie uregulowane społeczno-polityczne, występujące w określonym czasie, zjawisko, polegające na tym, że upoważnione podmioty postępują zgodnie z ustalonymi procedurami wyborczymi (s. 564). Podmioty procesu wyborczego to: wyborcy, kandydaci, partie polityczne jako podmioty wysuwania kandydatów, oficjalni obserwatorzy i komisje wyborcze (s. 568-574). W procesie tym biorą udział także inni uczestnicy, niemający statusu podmiotów procesu wyborczego (członkowie komisji wyborczych, organy władzy publicznej, sądy, środki masowej informacji - s. 575-578).

W dalszej części rozdziału J. Kluczkowski omawia różne koncepcje dotyczące wyodrębnienia etapów procesu wyborczego, a następnie zajmuje się jego aspektem temporalnym (s. 587-602). Do podstawowych zasad procesu wyborczego zalicza, i kolejno omawia, legalność procesu wyborczego i publiczny (otwarty) charakter procesu wyborczego (s. 606-613).

Przedmiotem zainteresowania autora recenzowanej monografii są także organy administracji wyborczej i związane z nimi zasady (rozdział IX). 
Charakteryzując status prawny tych organów miedzy innymi starał się odpowiedzieć na pytanie o ich miejsce w systemie podziału władzy (s. 626-629).

W doktrynie rosyjskiej organy administracji wyborczej traktowane są jako odrębna od ustawodawczej, wykonawczej i sądowniczej „władza wyborcza”. J. Kluczkowski nie podziela tego poglądu, przedstawia argumenty za zaliczaniem organów wyborczych do władzy wykonawczej (s. 629).

Zasady związane z organami administracji wyborczej to: zasada niezależności i bezstronności, zasada kolegialności, zasada jawności i zasada profesjonalizmu.

Interesujące są efekty badań komparatystycznych przedstawione w podrozdziałach dotyczących: formowania składu organów wyborczych, prawa do tego, by zostać członkiem komisji wyborczej oraz profesjonalnego przygotowania do roli członka komisji wyborczej (s. 658-682). Czytelnik znajduje tu między innymi informacje o różnych wariantach rozwiązań dotyczących tego, kto może być członkiem komisji wyborczej, kto proponuje kandydatów na członków komisji i kto ich wyznacza.

Ostatni rozdział monografii poświęcony został kodyfikacji prawa wyborczego jako optymalnemu instrumentowi zabezpieczenia zasad prawa wyborczego. Autor prezentuje się jako zdecydowany zwolennik uchwalenia kodeksu wyborczego Ukrainy. Przedstawia genezę idei kodyfikacji prawa wyborczego na Ukrainie, jej cel i zasady, omawia ustawodawstwo wyborcze Ukrainy jako przedmiot kodyfikacji, specyfikę kodyfikacji prawa wyborczego i wreszcie strukturę projektu kodeksu wyborczego Ukrainy (s. 683-763). Jako załącznik monografia zawiera konkretną propozycję takiej struktury złożonej z 652 artykułów podzielonych na trzy księgi (część ogólna, wybory ogólnokrajowe i wybory lokalne), 15 rozdziałów i 52 podrozdziały.

Zasadniczym walorem recenzowanej monografii jest ogromny zasób wiedzy jakiej dostarcza. J. Kluczkowski każde z poruszanych zagadnień ilustruje nie tylko wieloma przykładami rozwiązań przyjętych we współczesnym prawie wyborczym, ale także, co szczególnie cenne, szczegółowo analizuje poglądy doktryny nie tylko ukraińskiej, ale również, a może nawet przede wszystkim, doktryny prawa wyborczego innych państw. Powołuje się na poglądy uczonych zarówno z państw o utrwalonej demokracji, jak i na przykład doktryny rosyjskiej i innych państw postradzieckich, w której wciąż odczuwalne są echa poglądów z tamtych czasów. Polskiego czytelnika z pewnością pozytywnie zaskoczy to, jak istotne dla autora i jak często powoływane są ustalenia polskiej doktryny prawa konstytucyjnego.

Krzysztof Eckhardt*

* ORCID: 0000-0003-3338-9836. 